\title{
A Study on the Defect Detection Algorithm by Interval Statistical Processing Method of Arc Welding Waveform
}

\section{아크용접파형의 구간통계처리법에 의한 결함검출 알고리즘 연구}

\author{
Woo-Hyeon Ju*, Hyeong-Chang Ryu*, Kyeong-Seob Lim*, Jong-Jung Lee*, \\ Yong-Hwan Park* and Sang-Myung Cho**, \\ *Dept. of Mechanical Engineering, Pukyong Nat'1 Univ., Busan, 48513, Korea \\ **Welding Technology Center for fusion materials \& Components, Pukyong Nat'l Univ., Busan, 48513, Korea \\ (Received November 29, 2020; Revised December 16, 2020; Accepted December 24, 2020)
}

†Corresponding author: pnwcho@naver.com

\begin{abstract}
Defects in flux cored arc welding (FCAW) using $\mathrm{CO}_{2}$ gas not only deteriorate the quality of the welded part, but also increase the overall quality cost (Q-cost) due to the need for maintenance and welding. Destructive inspection and non-destructive inspection are two methods used to detect defects, but they are costly and time consuming. An alternate and advanced technique of detecting defects is by using a welding waveform. However, when the unprocessed welding waveform is checked, it is difficult to distinguish between normal and abnormal waveforms according to the metal transfer mode. This is because the waveforms are significantly different based on whether or not a short circuit occurs. Therefore, an algorithm that can detect defects from waveforms, independent of the presence of a short circuit, is required. The developed algorithm should be able to detect defects using welding waveforms. In this study, we provide a method to detect defects by using the interval statistical processing method, according to the time series of welding data displayed in the welding monitoring system.
\end{abstract}

Key Words: FCAW, Defect detection, Waveform, Interval statistical processing method

\section{Introduction}

Defects in flux cored arc welding (FCAW) using $\mathrm{CO}_{2}$ gas causes the increase in the overall quality cost (Q-cost). Destructive and non-destructive inspection methods can be employed for detecting defects, but these methods are not the most effective approach in terms of time and cost. As a more advanced technique, the defects can be detected by welding waveforms ${ }^{1,2)}$.

However, when unprocessed welding waveforms are examined, it is difficult to distinguish between normal and abnormal waveforms according to the metal transfer mode. This is because waveforms are considerably different depending on the presence or absence of a short circuit in FACW. Therefore, there is a need for an algorithm that can detect defects from waveforms regardless of the presence of a short circuit.

In this context, the purpose of this study is to develop a defect detection algorithm by using the interval statistical processing method in which information on welding condition shown in the welding current and voltage waveforms is represented in time series.

In the experiment, for bead on plate welding with FCAW, under a constant current condition, the contact tip to work distance (CTWD) and voltage were adjusted to create an unstable welding condition and in this way, the detection algorithm was tested on the presence or absence of the defects for verification of the developed algorithm.

\section{Methods}

\subsection{Materials}

The base metal used in this study was SS400 with a length at $150 \mathrm{~mm}$, a width at $125 \mathrm{~mm}$ and a thickness at $9 \mathrm{~mm}$, and for the filler metal, ø1.2 $\mathrm{mm}$ flux cored 
wire(AWS A5. 20) was used. Bead on plate welding was performed using Hyosung PFC 600 A DC inverter type welding machine shown in Fig. 1. For the measurement of welding waveforms, Welteq welding monitoring system shown in Fig. 2 was used. Signal filtering was performed for proper representation of the welding phenomenon, and the measurement frequency was set to $10 \mathrm{kHz}$

\subsection{Experimental method}

The length of the welding line on the base metal plate was $130 \mathrm{~mm}$, and the welding speed was $30 \mathrm{~cm} / \mathrm{min}$. Table 1 shows the experimental conditions in which different values of CTWD were set according to the voltage.

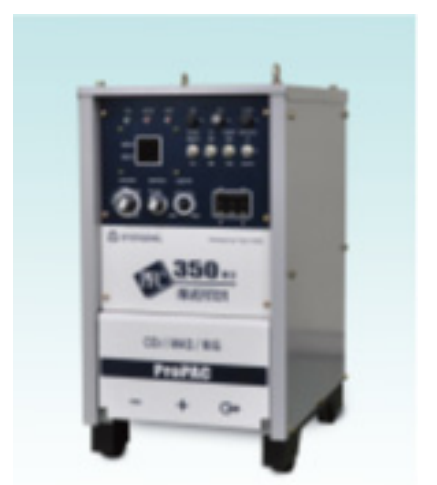

Fig. 1 Hyosung PFC 600A DC Inverter power source

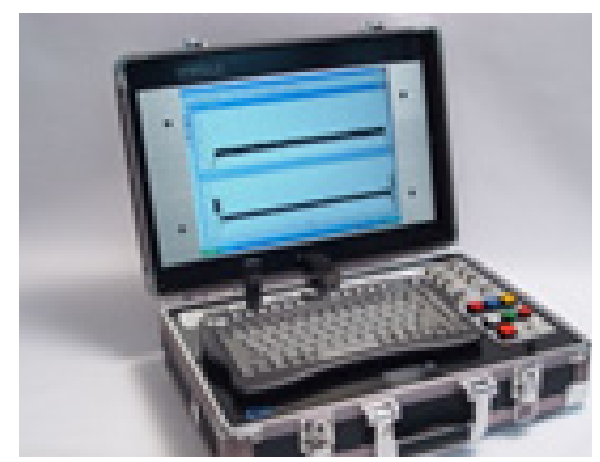

Fig. 2 Welteq arc welding monitoring system

Table 1 Bead on plate experiment condition

\begin{tabular}{|c|c|}
\hline Filler metal & AWS A5.20 E71T-1C $1.2 \mathrm{~mm}$ \\
\hline Base metal & SS400 $150 \times 125 \times 9 \mathrm{~mm}$ \\
\hline Shield gas & $100 \% \mathrm{CO}_{2}(15 \mathrm{~L} / \mathrm{min})$ \\
\hline Current & $200 \mathrm{~A}$ \\
\hline Welding speed & $30 \mathrm{~cm} / \mathrm{min}$ \\
\hline Voltage $[\mathrm{V}]$ & $19,21.5,24,26.5,29$ \\
\hline CTWD $[\mathrm{mm}]$ & $10,15,20,25,30$ \\
\hline
\end{tabular}

\section{Result and Discussion}

\subsection{Analysis of relationship between welding waveforms and defects}

In this study using FCAW for welding, with reference to the short circuit time of $10 \mathrm{~ms}$, if the time was shorter than $10 \mathrm{~ms}$, the case was defined as normal short circuit, and if the time was longer, it was defined as prolonged short circuit ${ }^{3)}$.

Fig. 3 shows the welding waveforms and radiographic test (RT) film results when the welding was performed under conditions of $29.0 \mathrm{~V}$ in voltage with the reference CTWD 15 (hereinafter condition A). The figure shows the case of a free flight without short circuit, and no defects were identified.

Fig. 4 shows the welding waveforms and RT film results when the welding was performed under conditions of $19.0 \mathrm{~V}$ in voltage with CTWD value of 15 (hereinafter condition B). In this figure, multiple cases of short circuit occurred but no defects were identified

Fig. 5 shows the welding waveforms and RT film results when the welding was performed under conditions of $19.0 \mathrm{~V}$ in voltage with CTWD at 20 (hereinafter condition C). In this study, the C level defined in the ISO 5817

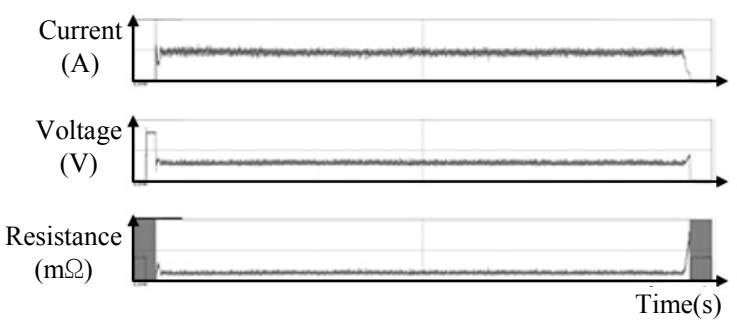

(a) Waveform of condition $\mathrm{A}$

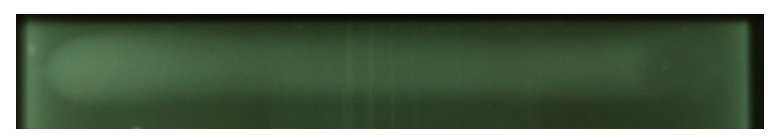

(b) RT film of condition A

Fig. 3 Waveform and RT film of condition A

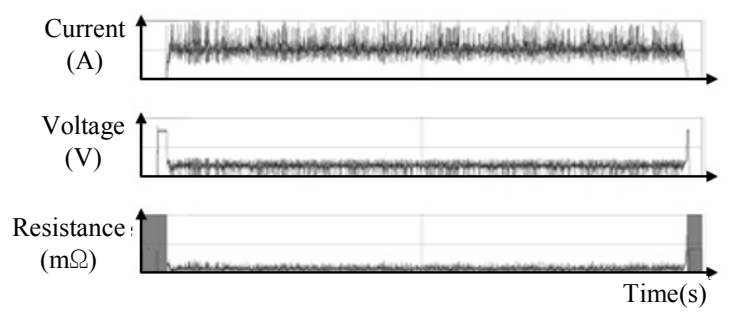

(a) Waveform of condition B

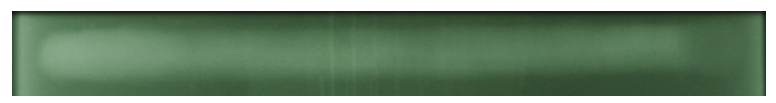

(b) RT film of condition B

Fig. 4 Waveform and RT film of condition B 


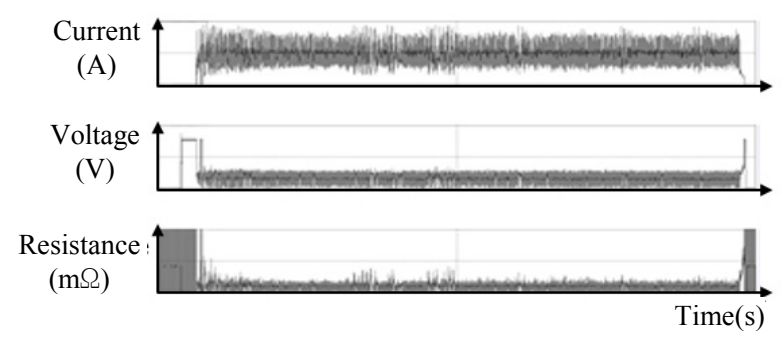

(a) Waveform of condition $\mathrm{C}$

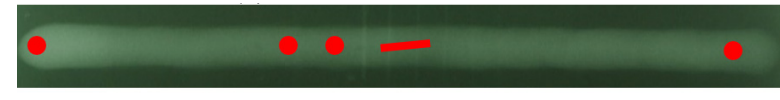

(b) RT film of condition C

Fig. 5 Waveform and RT film of condition C

specification was used as a reference, and defects that are larger than this level are represented in red in Fig. 5(b) for visualization. In this case, it can be seen that defects occurred in case of prolonged short circuit and at locations of arc-extinguish.

\subsection{Defect occurrence modeling through waveform analysis}

Fig. 6 shows the enlarged waveform for 0.5 seconds under condition $\mathrm{C}$ in which the short circuits were shown. The interval $\left(b_{1}-b_{2}\right)$ is a place where the short circuit lasted for $17 \mathrm{~ms}$ and is classified as prolonged short circuit.

Fig. 7 illustrates the melting phenomenon of the wire

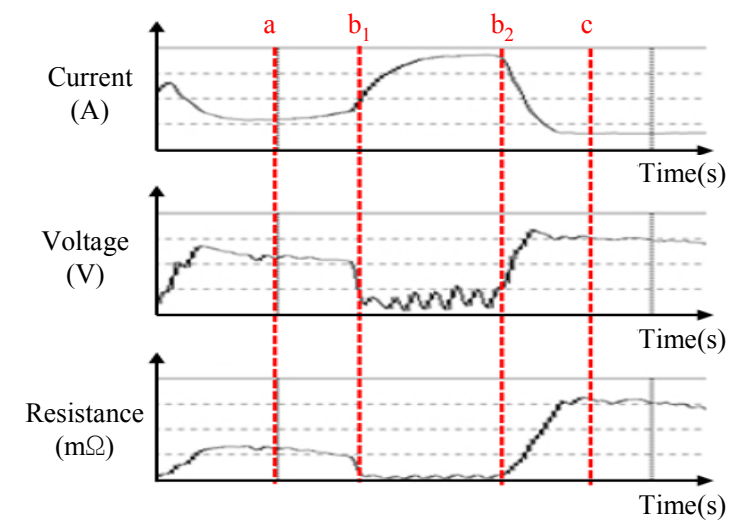

Fig. 6 Waveform of long term short circuit transfer (Condition $\mathrm{C}$ for $0.5 \mathrm{~s}$ )

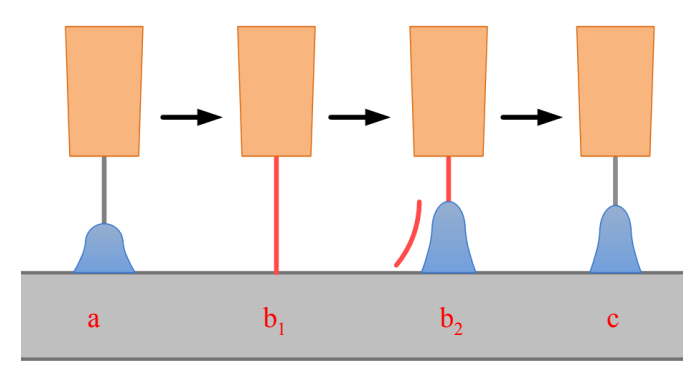

Fig. 7 Schematics of prolonged short circuit in case of prolonged short circuit. Due to the prolonged short circuit, overheating occurred from the resistance heating of the wire, which led to buckling in the middle location, and the wire is separated as in $\left(b_{2}\right)^{4,5)}$, resulting in arc strike and in this case, the arc length is longer than case of the normal welding. As a result, the voltage increased and the current decreased, resulting in a large resistance value. However, in reality, it was thought that the large resistance was obtained due to the long arc length, and as a result, the current decreased sharply and the voltage increased slightly. In this case, with long arc length under low current, the current density becomes too small, which makes melting of the base metal difficult, and this leads to the risk of lack of fusion or generation of weld pores.

Fig. 8 shows the enlarged waveform for 0.5 seconds under condition $\mathrm{C}$ in which arc-extinguish occurred. Fig. 9 illustrates the melting phenomenon of the wire in case of art-extinguish occurrence. In (a), after prolonged short circuit, sticking of the wire overheated due to the resistance heating occurred, leading to the buckling of wire at the contact tup end, leading to the separation of wire as shown in $\left(b_{1}\right)^{4,5)}$. At this time, arc is extinguished $\left(b_{1}\right)$, leading to lack of fusion or generation of weld pores. Subsequently, the wire is slowed down for arc restrike $\left(b_{2}\right)$, contacting the base metal and resulting in the arc restrike (c). During the wire slow-down, the current is 0 , no-load voltage occurs, and the resistance is infinite.

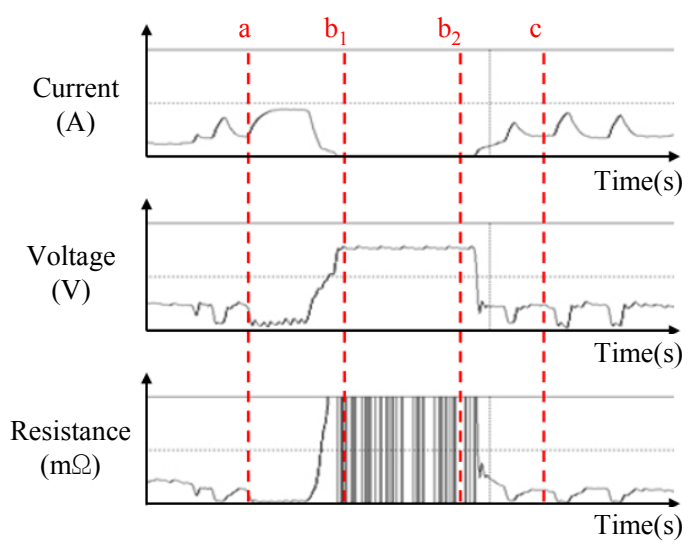

Fig. 8 Waveform of arc extinguish(Condition $\mathrm{C}$ for $0.5 \mathrm{~s}$ )

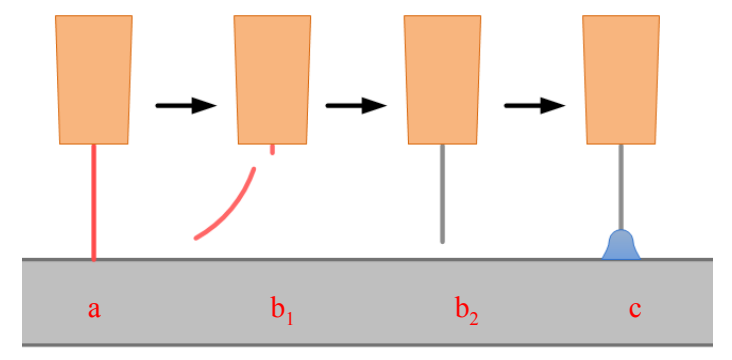

Fig. 9 Schematics of extinguished arc by wire sticking 


\subsection{Analysis of welding waveforms by interval statistical processing method}

\subsubsection{Overview of interval statistical processing method}

The interval statistical processing is a method proposed in this study, and it was defined that in this method, time series is divided into multiple intervals of a short time and statistical processing is performed separately for each interval to evaluate the welding stability for each interval of short time, enabling defect detection.

In the welding waveforms of FCAW, the current, voltage, and resistance vary rapidly with the metal transfer phenomenon occurring for a short duration ${ }^{7,8)}$. Therefore, welding data needs to be processed for analysis to detect defects using waveforms.

In the interval statistical processing method, the optimal interval length should be set in consideration of the frequency characteristics of the welding. If the interval is set to be too short, the normal short circuit and the prolonged short circuit cannot be distinguished, and if the interval is set to be too long, the defect detection accuracy is lowered. Therefore, this interval has the Nominal-the-best (NTB) characteristic.

In this section, in order to determine the optimal interval for defect detection using the waveforms of the welding resistance that increases 1) immediately after the prolonged short circuit and 2) at arc-extinguish, interval statistical processing was performed with the 5-sec data of conditions A, B, and C compared in Chapter

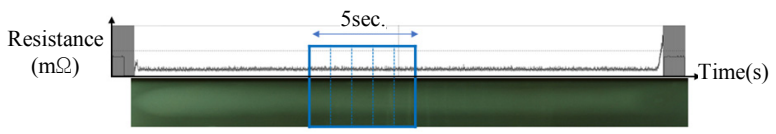

(a) Condition $\mathrm{A}$

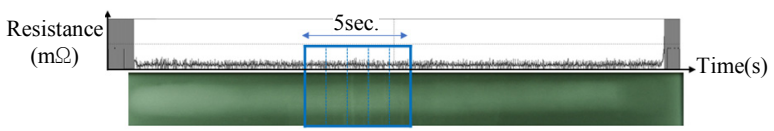

(b) Condition B

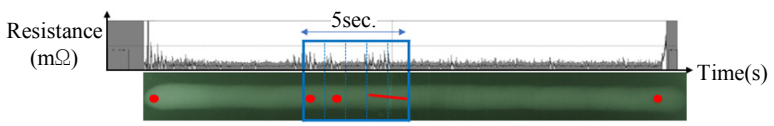

(c) Condition $\mathrm{C}$

Fig. 10 Waveforms and RT films

3 and compared after the processing. Fig. 10 shows the welding resistance waveforms and RT film results of conditions $\mathrm{A}, \mathrm{B}$, and $\mathrm{C}$ used for interval statistical processing. Using the welding monitoring system, 50,000 of 5-sec resistance data were analyzed acquired at a sampling rate of $10 \mathrm{kHz}$ per second, and a total of 5 sizes intervals were comparatively analyzed which are 1 second, 0.5 seconds, 0.1 seconds, 0.05 seconds, and 0.01 seconds for analysis of the optimal time series interval.

\subsubsection{Result of interval statistical processing}

For 5-sec duration data of defects in Fig. 10, in Fig. 11 , further division of intervals into $1.0,0.5,0.1,0.05$

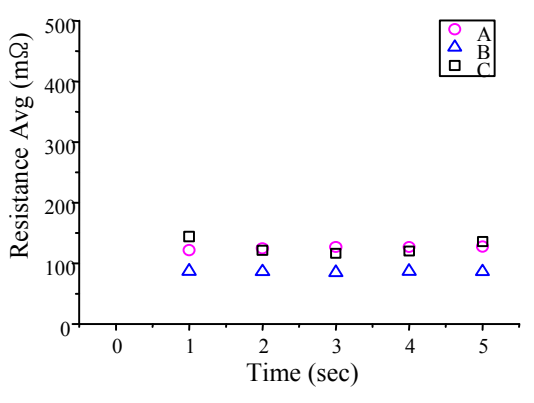

(a) Time series interval : $1 \mathrm{~s}$

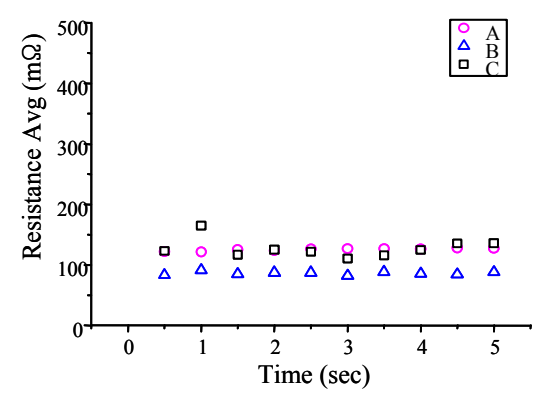

(b) Time series interval : $0.5 \mathrm{~s}$

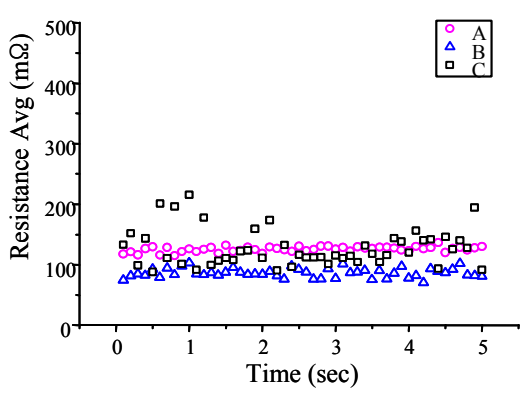

(c) Time series interval : $0.1 \mathrm{~s}$

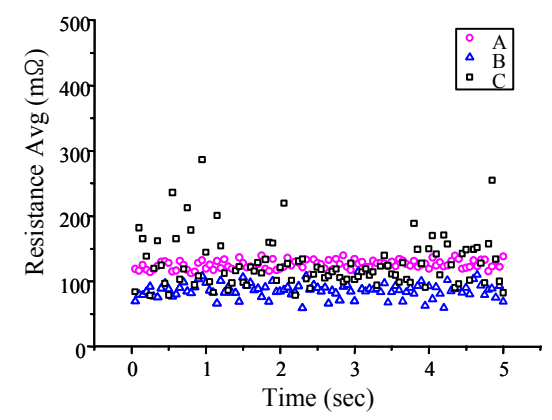

(d) Time series interval : $0.05 \mathrm{~s}$

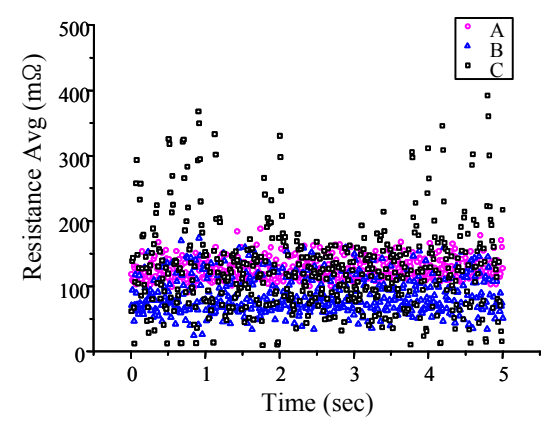

(e) Time series interval : $0.01 \mathrm{~s}$

Fig. 11 Interval statistic results of resistance average 
and $0.01 \mathrm{sec}$ was performed and the average welding resistance $R_{a v g}$ was represented for each small time series interval. In (a), and (b), the distinction between the defect part and non-defective part was not clear, and in (e), for 5-sec duration, stable data was obtained around $3 \mathrm{sec}$ interval but in case of 1-2 sec intervals and 4-5 sec intervals, data with values twice higher than the stable average value was obtained, indicating that the data in these intervals were unstable. In this study, it was thought that defects may occur in the intervals where these high-value data are obtained. On the other hand, (d) did not show the distinctive characteristic of high value data.

Figs. 12-14 show the standard deviation, maximum, and minimum of welding resistance, respectively, for each size of interval.

Table 2 shows the results of the interval statistical processing of resistance waveforms by comparing for each time series interval. As a result of analyzing resistance_avg, the defect detection result showed a high level of agreement at time series intervals of $0.05 \mathrm{sec}$ and $0.01 \mathrm{sec}$. As a result of analyzing resistance_st dev, the defect detection result showed a high level of agreement at time series interval of $0.05 \mathrm{sec}$. As a result of analyzing resistance_max, the defect detection result showed a high level of agreement at time series intervals of $0.1 \mathrm{sec}, 0.05 \mathrm{sec}$ and $0.01 \mathrm{sec}$. As a result of analyzing resistance_min, the defect detection result showed a high level of agreement at time series interval of $0.01 \mathrm{sec}$.

When resistance_max was analyzed, defect detection was possible in all intervals at $0.01 \mathrm{sec}, 0.05 \mathrm{sec}$ and $0.1 \mathrm{sec}$, but in terms of data processing efficiency, 0.1 sec interval was determined to be most optimum.

Therefore, for defect detection, the analysis parameter showing the highest performance of detection when compared to the actual locations of defects is resistance_max and in this case, the optimal time series interval is thought to be $0.1 \mathrm{sec}$.

Hong $^{6)}$ proposed a welding defect analysis method with application of moving average filter to welding data for quality analysis of welded parts. At sampling frequency of $10 \mathrm{kHz}, 2000$ data were selected and processed to remove signal irregularities. In this case, it is considered that it may be difficult to evaluate the instability of a specific interval because the welding signal values generated in the interval are averaged.

However, in this study, a basic algorithm to determine the presence/absence and location of defects was developed using the maximum arc resistance (arc length) obtained with $0.1 \mathrm{sec}$ interval.

\section{Conclusion}

In this study, for FCAW of carbon steel, a defect detection algorithm was developed by the interval statistical

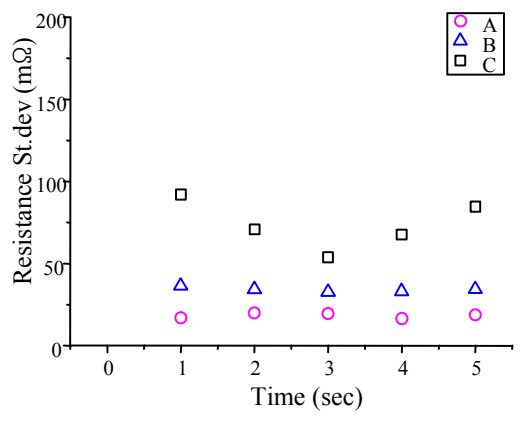

(a) Time series interval : $1 \mathrm{~s}$

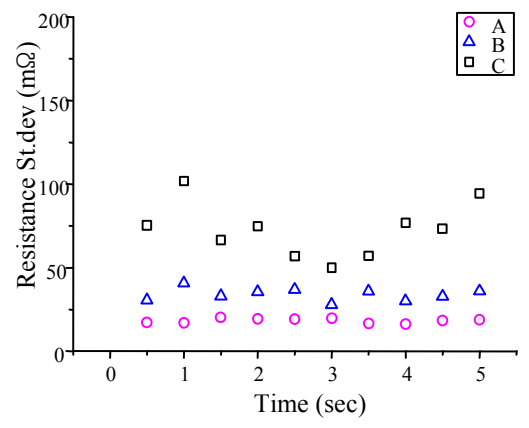

(b) Time series interval : $0.5 \mathrm{~s}$

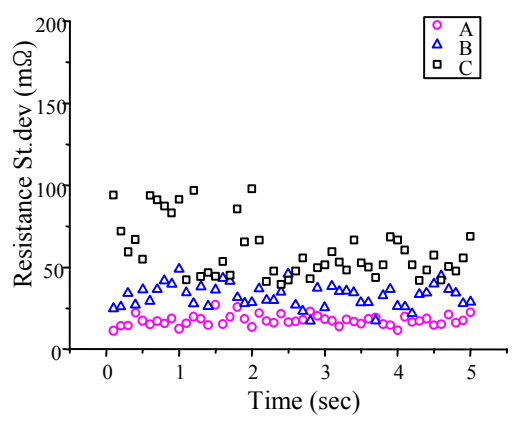

(c) Time series interval : $0.1 \mathrm{~s}$

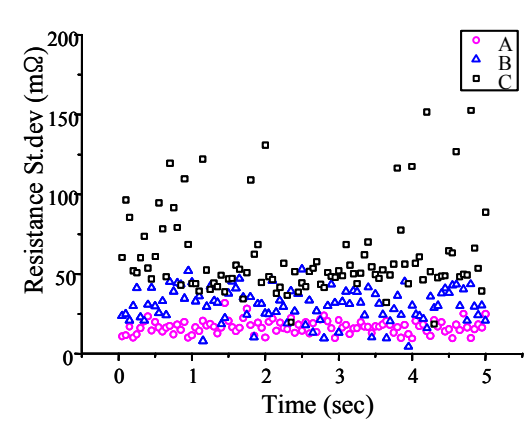

(d) Time series interval : $0.05 \mathrm{~s}$

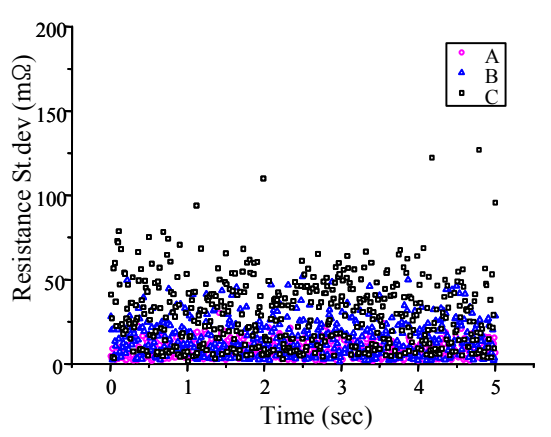

(e) Time series interval : $0.01 \mathrm{~s}$

Fig. 12 Interval statistic results of resistance st.dev 


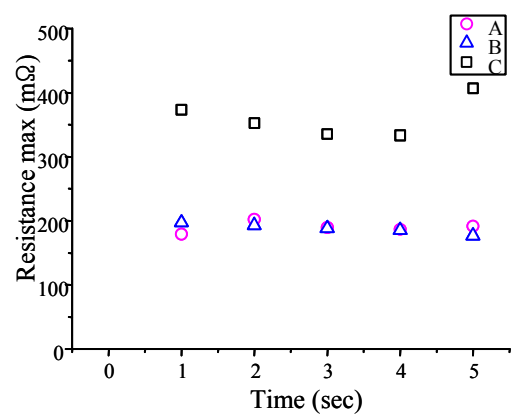

(a) Time series interval $: 1 \mathrm{~s}$

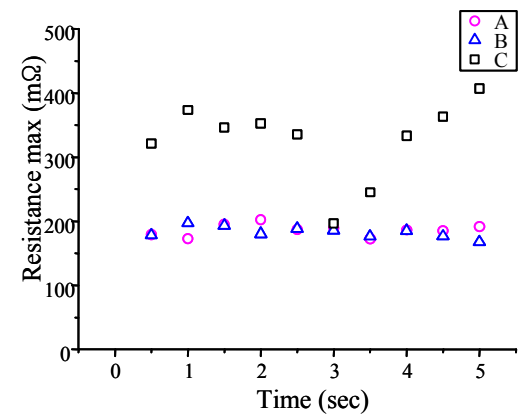

(b) Time series interval : $0.5 \mathrm{~s}$

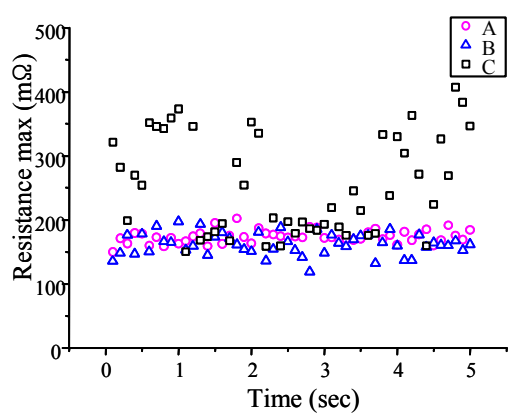

(c) Time series interval : $0.1 \mathrm{~s}$

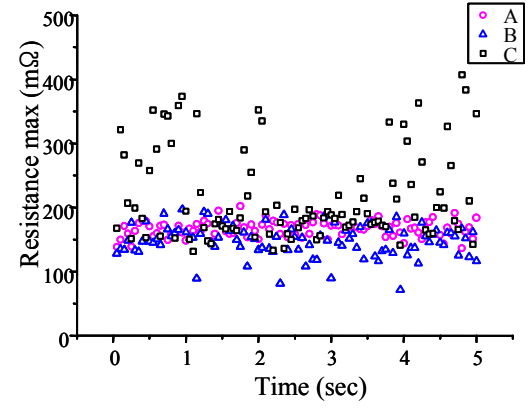

(d) Time series interval : $0.05 \mathrm{~s}$

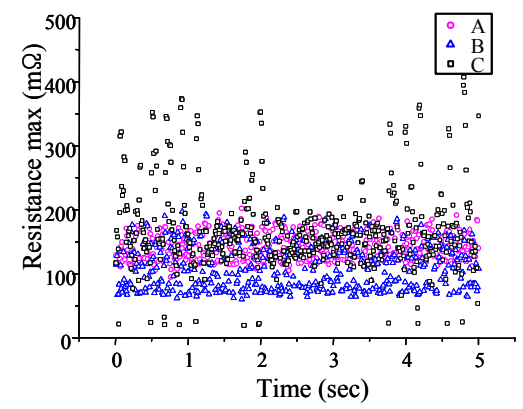

(e) Time series interval : $0.01 \mathrm{~s}$

Fig. 13 Interval statistic results of resistance max

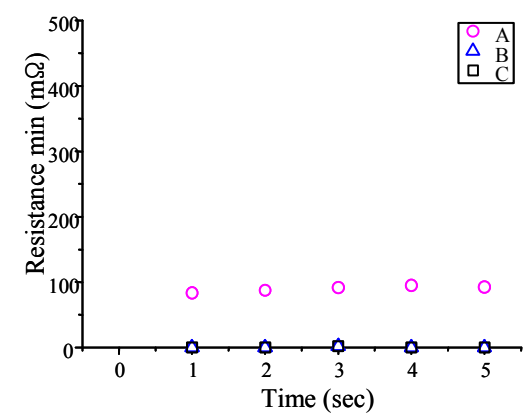

(a) Time series interval : $1 \mathrm{~s}$

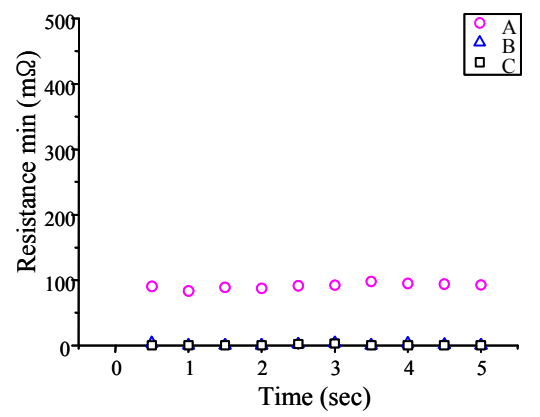

(b) Time series interval : $0.5 \mathrm{~s}$

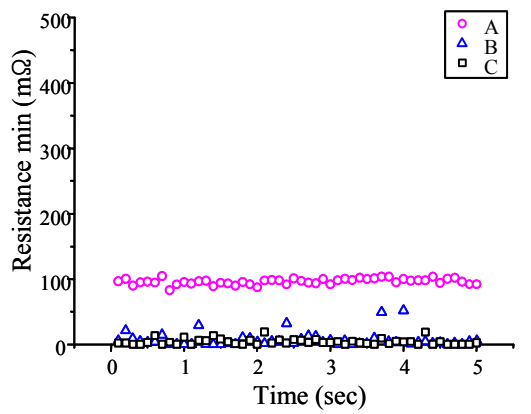

(c) Time series interval : $0.1 \mathrm{~s}$

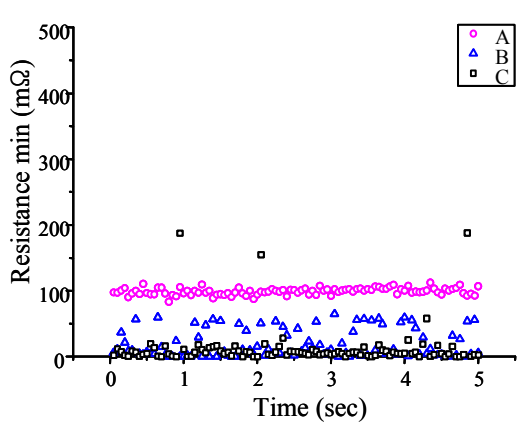

(d) Time series interval : $0.05 \mathrm{~s}$

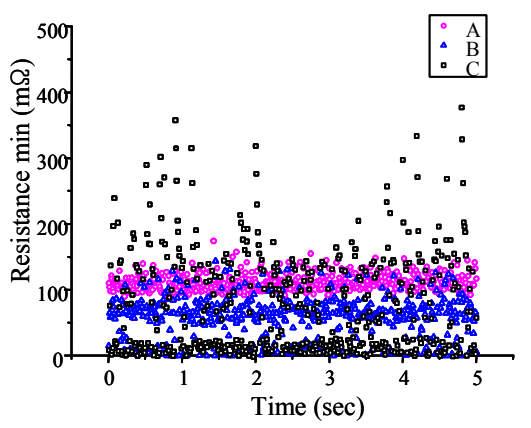

(e) Time series interval : $0.01 \mathrm{~s}$

Fig. 14 Interval statistic results of resistance min

processing method of the arc welding waveforms and the detection result was compared with the RT result of the sample with defects. The following conclusions were derived from the analysis.
1) The results of this study presented that after the occurrence of prolonged short circuit, at arc restrike, the arc length was longer, leading to considerably low current and large resistance, and this resulted in lack of 
Table 2 Comparison of the correspondence for defect detection

\begin{tabular}{|c|c|c|c|c|c|}
\hline & \multicolumn{5}{|c|}{ Time series interval (s) } \\
\hline & 1 & 0.5 & 0.1 & 0.05 & 0.01 \\
\hline $\mathrm{R}_{\text {avg }}$ & Low & Low & Middle & High & High \\
\hline $\mathrm{R}_{\text {st.dev }}$ & Low & Low & Low & High & Low \\
\hline $\mathrm{R}_{\max }$ & Low & Low & High & High & High \\
\hline $\mathrm{R}_{\min }$ & Low & Low & Low & Low & High \\
\hline
\end{tabular}

fusion or generation of weld pores.

2) When the arc is extinguished by wire sticking, the current is 0 , a no-load voltage occurs, and the resistance becomes infinite. Therefore, the detection of the arcextinguish can be easily performed through resistance waveforms, and the arc-extinguish resulted in lack of fusion or generation of weld pores.

3) When using resistance_max for each interval in the welding waveforms, defect detection was achieved in all intervals at $0.01 \mathrm{sec}, 0.05 \mathrm{sec}$, and $0.1 \mathrm{sec}$ and in consideration of data processing efficiency, $0.1 \mathrm{sec}$ interval was determined to be the optimal duration of the interval.

\section{Acknowledgements}

We acknowledge that this study is funded by research grant from KEIT, South Korean Ministry of Trade, Industry and Energy. [No : 20003633]

ORCID: Woo-Hyeon Ju: https://orcid.org/0000-0002-3140-8004 ORCID: Hyeong-Chang Ryu: https://orcid.org/0000-0001-5382-6795 ORCID: Kyeong-Seob Lim: https://orcid.org/0000-0001-6733-0643 ORCID: Jong-Jung Lee: https://orcid.org/0000-0003-2414-3906 ORCID: Yong-Hwan Park: https://orcid.org/0000-0002-5280-2764 ORCID: Sang-Myung Cho: https://orcid.org/0000-0001-6258-3625

\section{Reference}

1. T. Quinn, C. Smith, C. McCowan, E. Blachowiak and R. Madigan, Arc sensing for defects in constant-voltage Gas Metal Arc Welding, Weld. J. 79 (1999) 322-328.

2. S. Adolfsson, A. Bahrami, G. Bolmsjo and I. Claesson, On-line quality monitoring in short circuit gas metal arc welding, Weld. J. 78 (1999) 59-73.

3. Y. Chu, S. Hu, W. Hou, P. Wang and S. Marin, Signature analysis for quality monitoring in short-circuit GMAW, Weld. J. 83 (2004) 336-343.

4. D. Farson, C. Conardy, J. Talkington, K. Baker, T. Kerschbaumer and P. Edwards, Arc initiation in Gas Metal Arc Welding, Weld. J. 77 (1998) 315-321.

5. E. Choi, J. Y. Kim, S. H. Shin, S. Y. Kim, A study on the analysis effectiveness of the virtual welding simulator for welding manpower development, J. Weld. Join. 33(3) (2015) 40-46. https://doi.org/10.5781/JWJ.2015.33.3.40

6. W. H. Hong, J. T. Ryu, A study on the welding current and voltage signal processing method for the quality evaluation of robotic GMAW, J. Korea Industr. Inf. Syst. Res.(KSIIS), 19(6) (2014) 321-325. https://doi.org/10.9723/jksiis.2014.19.6.025

7. B. W. Seo, Y. C. Jeong, Y. T. Cho, A study on the Selection of Arc Sensing Signal for Seam Tracking in Pulsed GMAW, J. Weld. Join. 38(2) (2020) 173-179. https://doi.org/10.5781/JWJ.2020.38.2.7

8. J. Y. Park, S. H. Song, Study on the Evaluation of Weld Soundness Based on Arc Stability and Bead Quality using the Statistical Analysis of Arc Power and Arc Dynamic Resistance, J. Weld. Join. 37(6) (2019) 599-604. https://doi.org/10.5781/JWJ.2019.37.6.10 


\title{
아크용접파형의 구간통계처리법에 의한 결함검출 알고리즘 연구
}

\section{A Study on the Defect Detection Algorithm by Interval Statistical Processing Method of Arc Welding Waveform}

\author{
주우현* · 류형창* - 임경섭* - 이종중* - 박영환 \\ *부경대학교 기계공학과 \\ **부경대학교 융복합부품소재 용접기술센터
}

\section{1. 서 론}

$\mathrm{CO}_{2}$ 가스를 사용하는 flux cored arc welding (FCAW) 에서 결함이 발생하면 종합적인 quality $\operatorname{cost}\left(\mathrm{Q}^{-} \cos \mathrm{t}\right)$ 가 증가하게 된다. 결함을 검출하는 방법은 파괴검사, 비파괴검사가 있지만 이러한 방법은 비용과 시간을 소 모하게 된다. 또한 보다 발전된 기술로서 용접파형을 통해 결함을 확인하는 방법이 있다1,2).

그러나 가공되지 않은 용접파형을 확인하게 되면 용 적이행모드에 따라 정상, 비정상 파형의 구분이 어렵 다. FCAW에서 단락의 발생 유무에 따라 파형이 현저 히 다르게 나타나기 때문이다. 따라서 단락유무와 상관 없이 파형으로부터 결함을 검출할 수 있는 알고리즘이 요구된다.

본 연구에서는 용접 전류, 전압 파형에 나타난 용접상 태 정보를 시계열로 나타낸 구간통계처리법에 의해 결함 을 검출하는 방법을 개발하는 것이 그 목적이다.

실험에서 FCAW로 bead on plate 용접하였을 때 일정한 용접전류에서, contact tip to work distance (CTWD)와 전압을 조절하여 불안정한 용접상태를 만 들었다. 이에 따른 결함발생 유무와 검출알고리즘에 대 한 검증을 거쳤다.

\section{2. 실험방법}

\section{1 실험 재료}

본 연구에 사용된 모재는 길이 $150 \mathrm{~mm}$ 폭 $125 \mathrm{~mm}$ 두께 $9 \mathrm{~mm}$ 의 SS400을 사용하였으며 용가재는 $\varnothing 1.2 \mathrm{~mm}$ flux cored wire(AWS A5. 20)을 사용하였다. 용접 전원으로 Fig. 1에 나타낸 Hyosung PFC 600 A DC inverter 용접기를 사용하여 bead on plate 용접하였

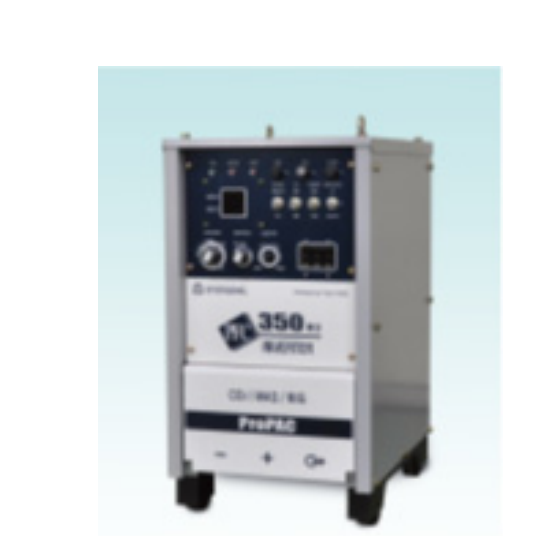

Fig. 1 Hyosung PFC 600A DC Inverter power source

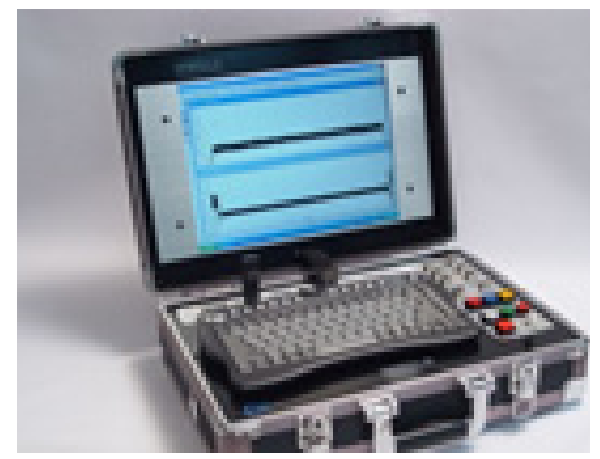

Fig. 2 Welteq arc welding monitoring system

다. 용접파형의 계측에는 Fig. 2에 나타낸 Welteq 용접 모니터링 시스템을 사용하였으며, 용접현상의 적절한 표 현을 위해 신호 필터링을 하였고 계측 주파수는 $10 \mathrm{kHz}$ 로 하였다.

\section{2 실험방법}

모재 판재 위에 용접선 길이를 $130 \mathrm{~mm}$ 로 하였고, 용접속도는 $30 \mathrm{~cm} / \mathrm{min}$ 이었다. Table 1에 전압 별로 $\mathrm{CTWD}$ 를 달리 설정한 실험 조건을 나타내었다. 
Table 1 Bead on plate experiment condition

\begin{tabular}{|c|c|}
\hline Filler metal & AWS A5.20 E71T-1C $1.2 \mathrm{~mm}$ \\
\hline Base metal & SS400 $150 \times 125 \times 9 \mathrm{~mm}$ \\
\hline Shield gas & $100 \% \mathrm{CO}_{2}(15 \mathrm{~L} / \mathrm{min})$ \\
\hline Current & $200 \mathrm{~A}$ \\
\hline Welding speed & $30 \mathrm{~cm} / \mathrm{min}$ \\
\hline Voltage $[\mathrm{V}]$ & $19,21.5,24,26.5,29$ \\
\hline CTWD $[\mathrm{mm}]$ & $10,15,20,25,30$ \\
\hline
\end{tabular}

\section{3. 실험결과 및 고찰}

\section{1 용접파형과 결함 간의 관계 검토}

FCAW를 사용하는 본 연구에서는 단락 유지 시간을 $10 \mathrm{~ms}$ 기준으로, 그 이하는 정상단락으로 정의하고, 그 이상은 장기단락으로 정의하였다 ${ }^{3)}$.

Fig. 3는 전압 $29.0 \mathrm{~V}$, 표준CTWD $15 \mathrm{~mm}$ 조건 (이하 조건A) 으로 용접하였을 때의 용접파형, radiographic test(RT) 필름 결과를 나타낸 것이다. 단락 이 없는 자유비행(Free flight)으로 나타났으며 결함 도 발생하지 않았다.

Fig. 4는 전압 $21.5 \mathrm{~V}, \mathrm{CTWD} 10 \mathrm{~mm}$ 조건 (이하 조 건B) 으로 용접하였을 때의 용접파형, RT필름결과를 나 타낸 것이다. 단락이 다수 발생하였으나 결함은 발생하 지 않았다.

Fig. 5는 전압 $19.0 \mathrm{~V}, \mathrm{CTWD} 20 \mathrm{~mm}$ 조건 (이하 조건C) 으로 용접하였을 때의 용접파형과 RT필름결과 를 나타낸 것이다. 본 연구에서는 ISO 5817 규격의 $\mathrm{C}$ 등급을 기준으로 하였고, 그 기준을 초과하는 크기의 결함을 Fig. 5 (b)에 알기 쉽게 붉은색으로 표기하였 다. 이때 장기단락과 아크꺼짐 위치에서 결함이 발생한 것을 알 수 있었다.

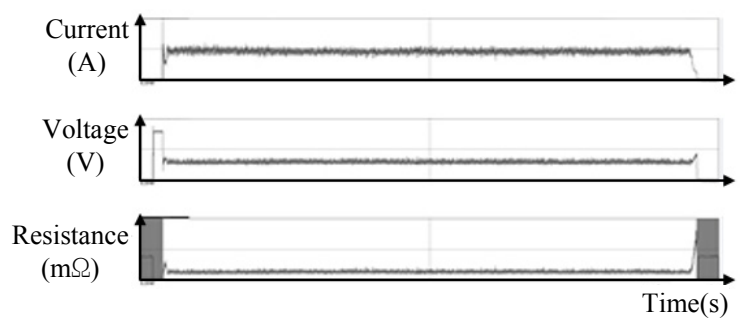

(a) Waveform of condition A

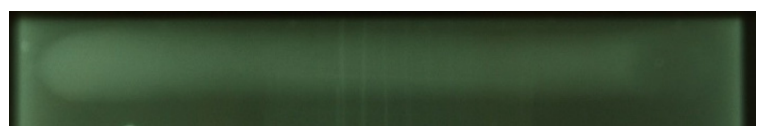

(b) RT film of condition A

Fig. 3 Waveform and RT film of condition A

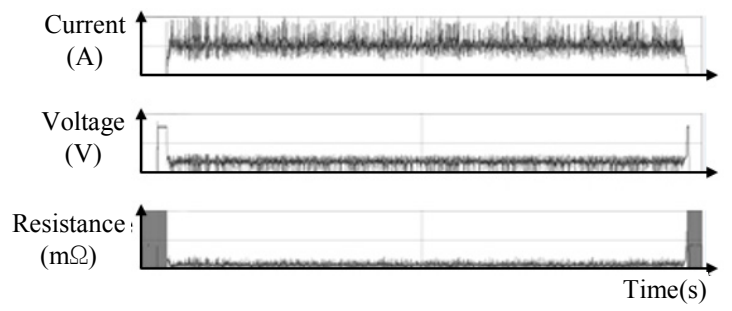

(a) Waveform of condition B

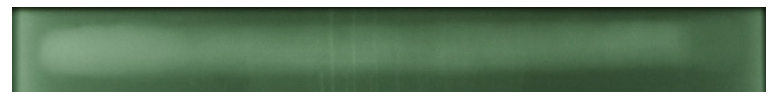

(b) RT film of condition B

Fig. 4 Waveform and RT film of condition B

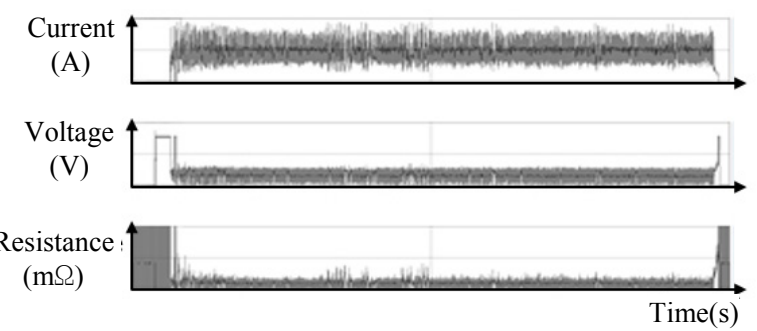

(a) Waveform of condition $\mathrm{C}$

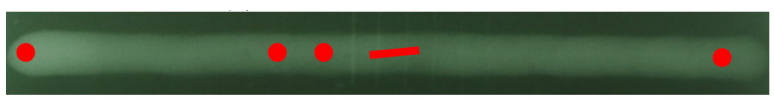

(b) RT film of condition C

Fig. 5 Waveform and RT film of condition C

\section{2 파형분석을 통한 결함 발생 모델링}

Fig. 6은 단락이 발생한 조건C의 0.5 초간 확대파형 을 나타낸 것이다. $\left(b_{1} \sim b_{2}\right)$ 구간은 $17 \mathrm{~ms}$ 동안 단락 이 발생하여 장기단락으로 분류된 곳이다.

Fig. 7은 장기단락이 발생하였을 때 와이어의 용융현 상을 모델링 한 것이다. 장기단락으로 와이어의 저항발 열로 인해 과열되어 중간지점에서 좌굴이 발생하여 $\left(\mathrm{b}_{2}\right)$ 와 같이 와이어가 탈락하면서 ${ }^{4,5)}$ 아크 재점호가 일어났

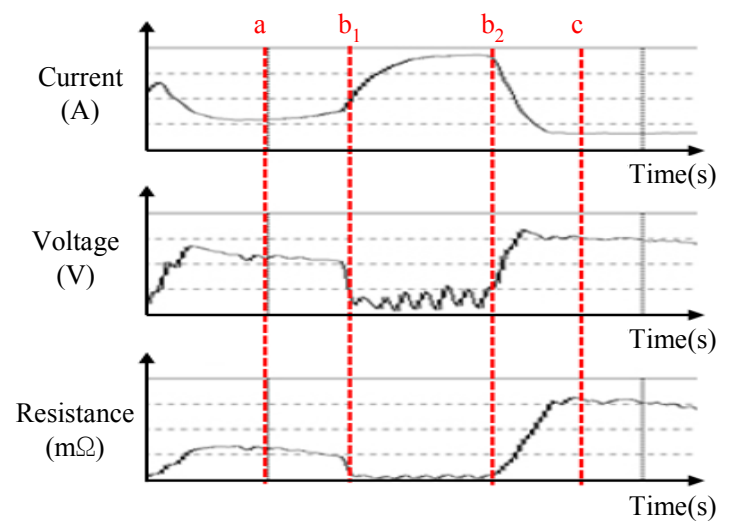

Fig. 6 Waveform of long term short circuit transfer (Condition $\mathrm{C}$ for $0.5 \mathrm{~s}$ ) 


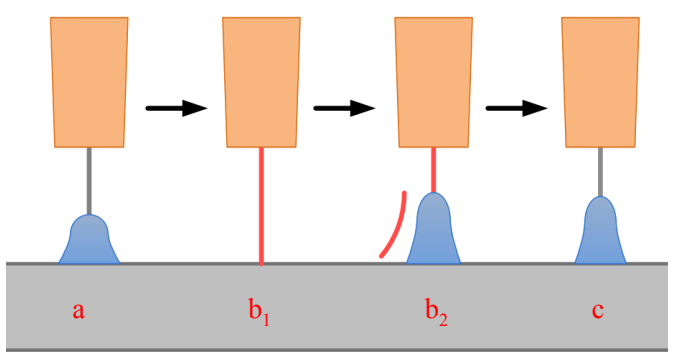

Fig. 7 Schematics of prolonged short circuit

으며 정상용접에 비해 아크길이가 커졌다. 그 결과 전 압이 증가하고 전류가 감소하여 큰 저항이 얻어졌다. 그러나 실제로는 긴 아크길이로 인해 큰 저항이 생기고 그로 인해 전류는 크게 감소하고 전압은 약간 증가하였 다고 판단되었다. 이때 저전류의 긴 아크길이의 순간에 는 전류밀도가 지나치게 낮아져 모재의 용융이 어려워 짐으로 융합불량 또는 기공 발생의 위험이 있다.

Fig. 8은 아크꺼짐이 발생한 조건 $\mathrm{C}$ 의 0.5 초간 확 대파형을 나타낸 것이다. Fig. 9는 아크꺼짐이 발생할 때 와이어 용융현상을 모델링한 것을 나타내었다. (a) 에서 장기단락 후 저항발열로 인해 과열된 와이어가 sticking에 의해 contact tip 선단에서 와이어가 좌굴을 일 으켜 $\left(\mathrm{b}_{1}\right)$ 과 같이 탈락하였다 ${ }^{4,5)}$. 그 순간 아크가 소멸 하여 $\left(b_{1}\right)$ 융합불량 또는 기공이 발생한다. 그 후 아크재

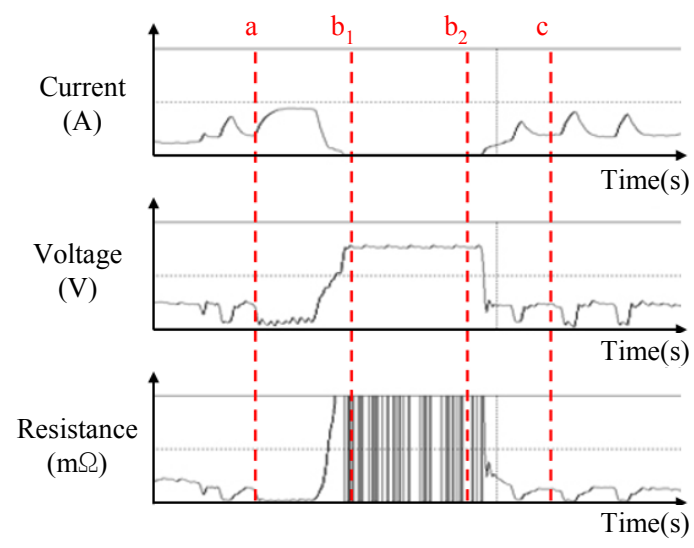

Fig. 8 Waveform of arc extinguish(Condition $\mathrm{C}$ for $0.5 \mathrm{~s}$ )

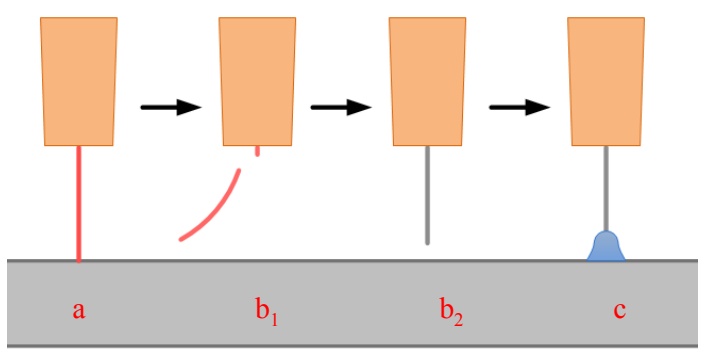

Fig. 9 Schematics of extinguished arc by wire sticking
점호를 하기 위해 와이어가 slow down되어 $\left(\mathrm{b}_{2}\right)$, 모재 에 접촉하여 아크재점호가 이루어진다(c). 와이어 slow down이 일어나는 동안 전류는 0 , 무부하전압이 발생 하며 저항은 무한대가 된다.

\section{3 구간통계처리법에 의한 용접파형 검토}

\subsection{1 구간통계처리법의 개요}

구간통계처리법은 본 연구에서 제안한 것으로서 시계 열을 짧은 시간의 여러 구간으로 나누어 그 구간 내에 서 통계처리를 별도로 하여 짧은 시간단위의 구간별 용 접 안정성 평가함으로써 결함을 검출하고자 하는 기법 으로 정의하였다.

$\mathrm{FCAW}$ 의 용접파형에서 전류, 전압, 저항은 짧은 시 간 동안 발생하는 용적이행 현상에 따라 급격하게 변동 한다 ${ }^{7,8)}$. 그러므로 파형을 이용하여 결함을 검출하기 위해 용접데이터를 가공하여 분석해야 한다.

구간통계처리에서 적절한 구간의 길이는 용접현상의 주파수특성을 고려하여 설정해야 된다. 너무 짧은 구간 을 설정하면 정상단락과 장기단락을 구분할 수 없게 되 며 너무 긴 구간을 설정하면 결함검출 정확도가 낮아지 게 된다. 따라서 이 구간은 망목특성을 가진다.

여기서는 장기단락 직후와 아크꺼짐 시 증가하는 용 접저항의 파형을 이용하여 결함을 검출할 수 있는 적절 한 구간을 파악하기 위해 3 장에서 비교한 조건 $\mathrm{A}, \mathrm{B}$, $\mathrm{C}$ 용접저항의 5 초간 데이터를 구간별 구간통계처리 하 여 비교하였다. Fig. 10은 구간통계처리에 사용된 조건 $\mathrm{A}, \mathrm{B}, \mathrm{C}$ 의 용접저항 파형과 $\mathrm{RT}$ 필름 결과를 나타내었 다. 용접모니터링 시스템을 이용하여 초당 $10 \mathrm{kHz}$ 의 샘플링속도로 획득한 5 초간 50,000 개의 용접저항 데 이터를 분석하였으며 적정 시계열구간을 분석하기 위해 1 초, 0.5 초, 0.1 초, 0.05 초, 0.01 초로 총 5 개의 구간 을 비교 분석하였다.

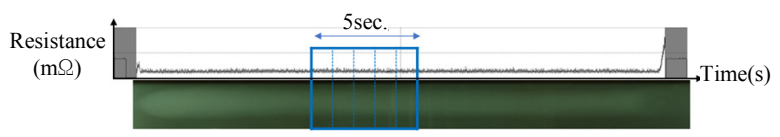

(a) Condition $\mathrm{A}$

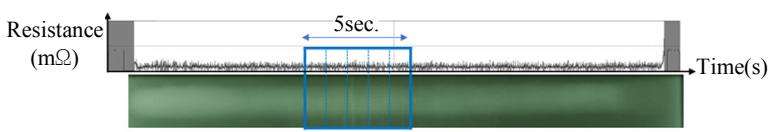

(b) Condition B

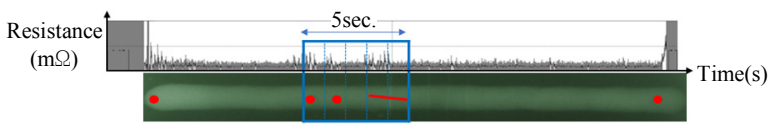

(c) Condition C

Fig. 10 Waveforms and RT films 


\subsection{2 구간통계처리 결과}

Fig. 11은 Fig. 10의 결함부5초에 대하여 미세구간 $1.0,0.5,0.1,0.05,0.01$ 초로 나누어 용접저항의 평균 $\mathrm{R}_{\mathrm{avg}}$ 을 미세구간별로 나타낸 것이다. (a), (b)에 서는 결함발생부와 건전한부분의 구분이 되지 않고, (e) 에서는 5 초의 기간중 3 초근방에서는 데이터가 안정된 특징을 보이지만, $1 \sim 2$ 초 구간과 $4 \sim 5$ 초구간에서는 안 정된 평균값의 2 배이상 높은 값의 데이터가 나타나 불 안정한 미세구간을 볼 수 있다. 본 연구에서는 이러한 높은 값의 데이터가 나타나는 미세구간에 결함이 발생 할 수 있다고 판단하였다. 한편 (d)는 높은 값의 데이 터가 뚜렷하게 나타나지 않는 특징을 보였다.

Fig. 12-14는 각각 저항의 표준편차, 최대, 최소를 미세구간별로 나타낸 것이다.

Table 2 는 저항의 구간통계처리 결과를 시계열 구 간별로 비교하여 나타내었다. 저항평균을 분석한 결과 $0.05,0.01$ 초 시계열구간에서 결함일치도가 높게 나타 났다. 저항표준편차를 분석한 결과 0.05 초 구간에서 결함일치도가 높게 나타났다. 저항최대를 분석한 결과 0.1초, 0.05 초, 0.01 초 구간에서 결함일치도가 높게 나타났다. 저항최소를 분석한 결과 0.01 초 구간에서 결함일치도가 높게 나타났다.

저항최대를 분석하였을 때 0.01초 구간, 0.05초 구 간, 0.1 초 구간 모두 결함검출이 가능하였으나 데이터 처리 효율성 면에서 0.1 초 구간이 가장 바람직한 것으
로 판단되었다.

따라서 결함을 검출함에 있어 실제 결함위치와 가장 분별력이 높은 분석 파라미터는 저항최대이며 이때 적 정 미세구간은 0.1 초인 것으로 판단된다.

$\mathrm{Hong}^{6)}$ 은 용접부 품질분석을 위해 용접데이터에 이 동평균필터를 적용하여 용접결함을 분석하는 방법을 제 시하였다. $10 \mathrm{kHz}$ 의 샘플링 주파수일 때 2000개의 데이터를 선택하여 신호의 불규칙성이 사라지게 처리하 였다. 이 경우 미세구간에서 발생하는 용접신호의 값이 평균화 되어 그 미세구간 특유의 불안정성을 평가하기 곤란할 수도 있다고 사료된다.

그러나 본 연구에서는 용접저항의 최대치(아크길이) 를 0.1 초 구간으로 계산하여 결함발생 여부와 위치를 판단할 수 있는 기본적 알고리즘을 제시하였다.

\section{4. 결 론}

탄소강의 $\mathrm{FCAW}$ 에서 아크용접파형의 구간통계처리 법에 의한 결함검출 알고리즘을 개발하여 결함발생시편 의 RT결과와 비교한 결과 다음과 같은 결론을 얻었다.

1) 장기단락이 발생한 후 아크 재점호시 아크길이가 길어지고 전류가 현저히 낮아지고 저항이 커져 융합불 량 또는 기공이 발생한다는 모델을 제시하였다.

2) 스티킹에 의해 아크가 소멸하면 전류는 0 , 전압 은 무부하전압이 되어 저항은 무한대가 되므로 아크꺼

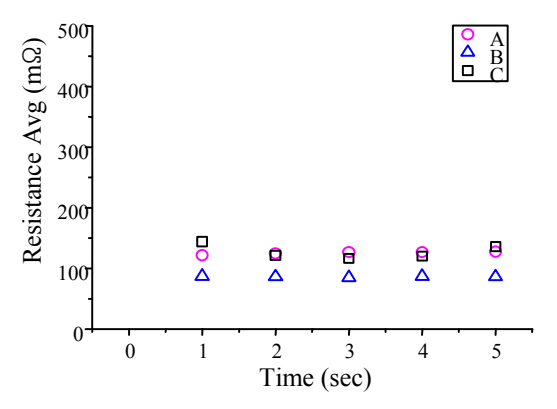

(a) Time series interval : $1 \mathrm{~s}$

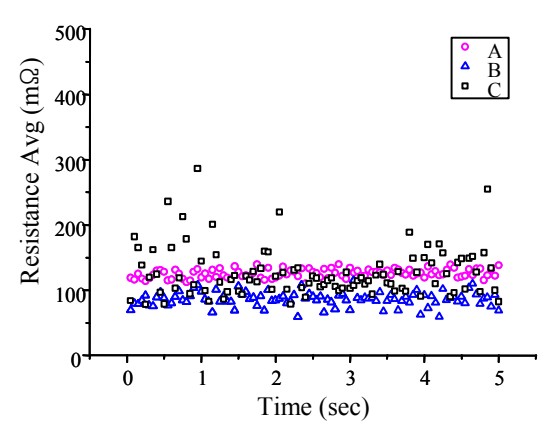

(d) Time series interval : $0.05 \mathrm{~s}$

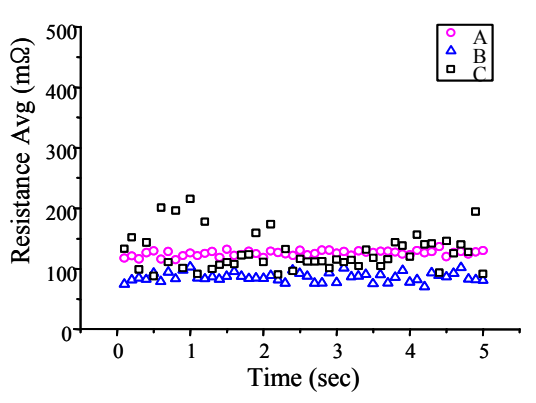

(c) Time series interval : $0.1 \mathrm{~s}$

Fig. 11 Interval statistic results of resistance average 


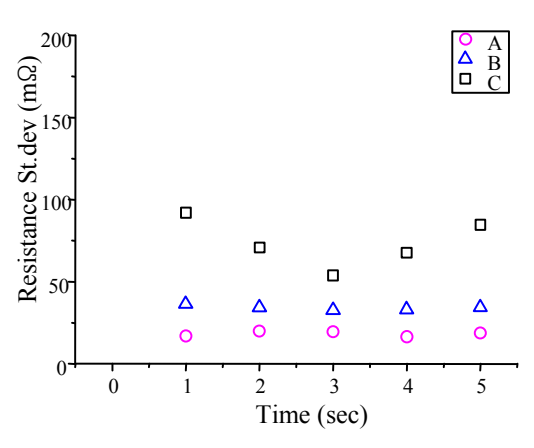

(a) Time series interval : $1 \mathrm{~s}$

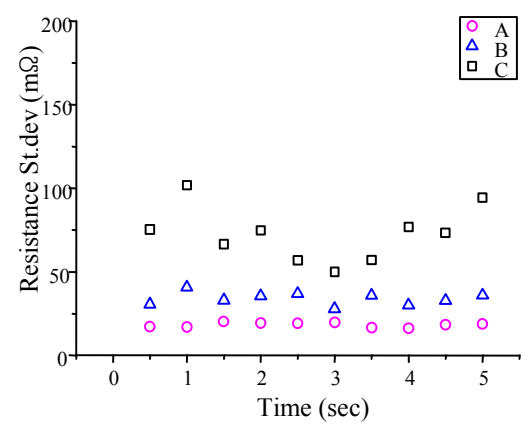

(b) Time series interval : $0.5 \mathrm{~s}$

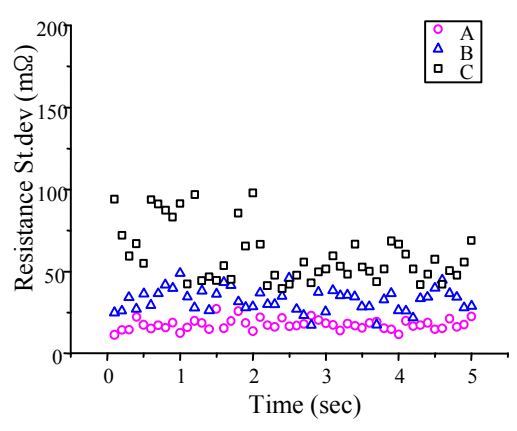

(c) Time series interval : $0.1 \mathrm{~s}$

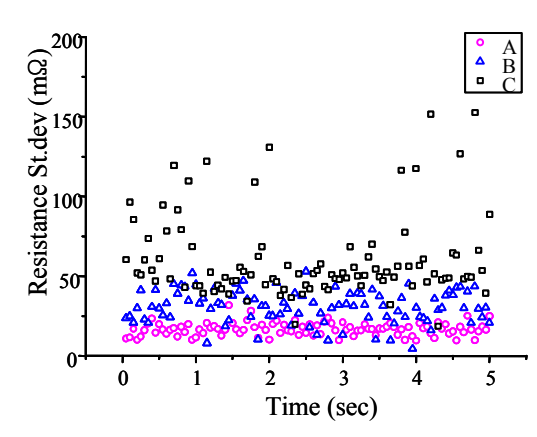

(d) Time series interval : $0.05 \mathrm{~s}$

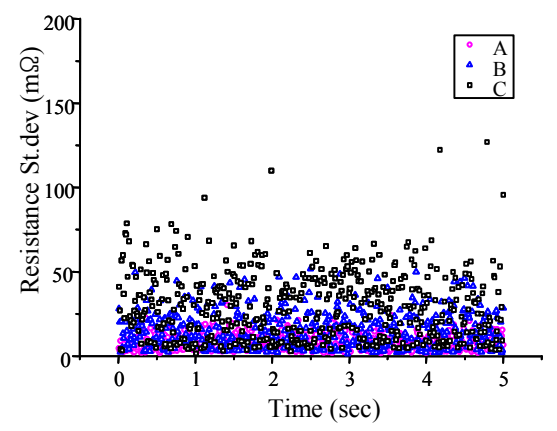

(e) Time series interval : $0.01 \mathrm{~s}$

Fig. 12 Interval statistic results of resistance st.dev

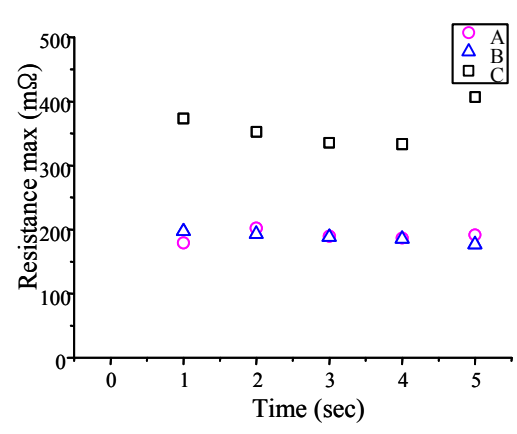

(a) Time series interval : $1 \mathrm{~s}$

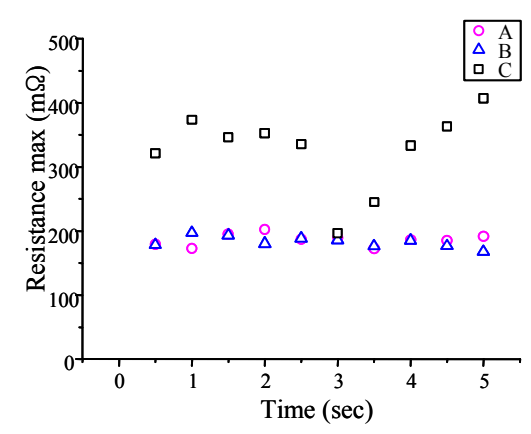

(b) Time series interval $: 0.5 \mathrm{~s}$

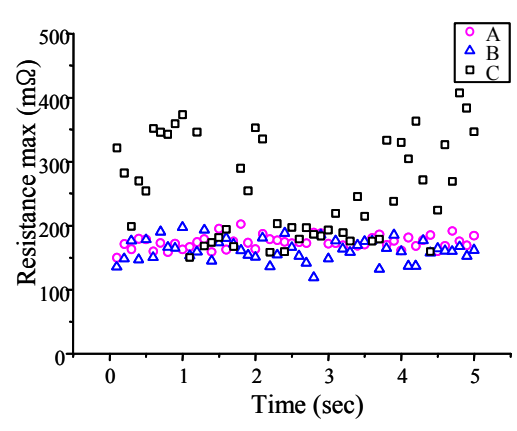

(c) Time series interval : $0.1 \mathrm{~s}$

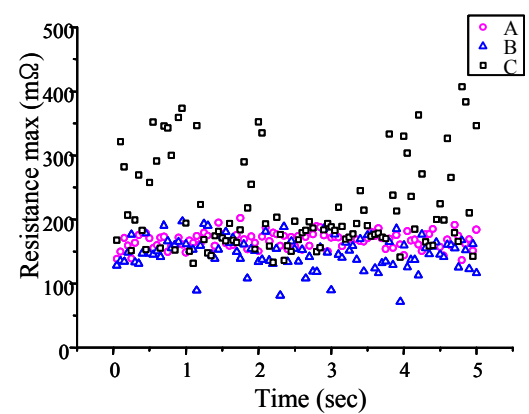

(d) Time series interval : $0.05 \mathrm{~s}$

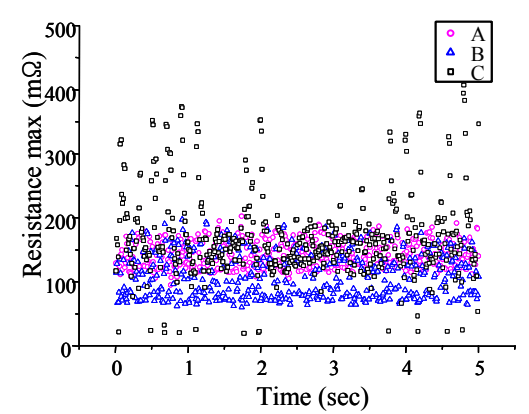

(e) Time series interval : $0.01 \mathrm{~s}$

Fig. 13 Interval statistic results of resistance max

짐의 검출은 저항으로 쉽게 할 수 있고, 그로 인한 융 합불량 또는 기공발생의 모델을 제시하였다.

3) 용접파형에서 구간별 저항최대를 쓸 때 0.01초
구간, 0.05 초 구간, 0.1 초 구간 모두 결함검출이 가능 하였으나 데이터처리 효율성 면에서 0.1 초 구간이 가 장 바람직한 것으로 판단되었다. 


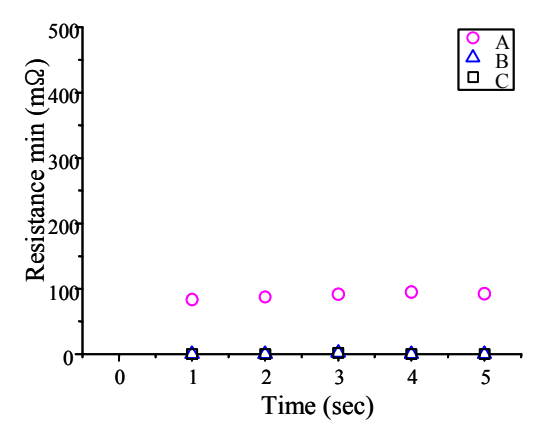

(a) Time series interval : $1 \mathrm{~s}$

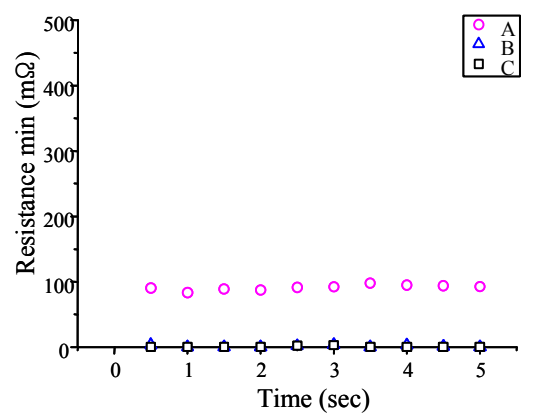

(b) Time series interval : $0.5 \mathrm{~s}$

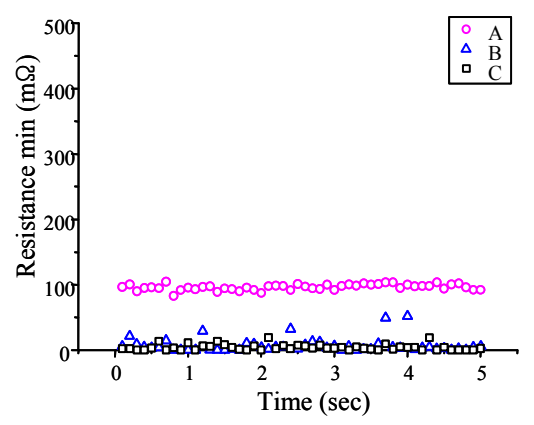

(c) Time series interval : $0.1 \mathrm{~s}$

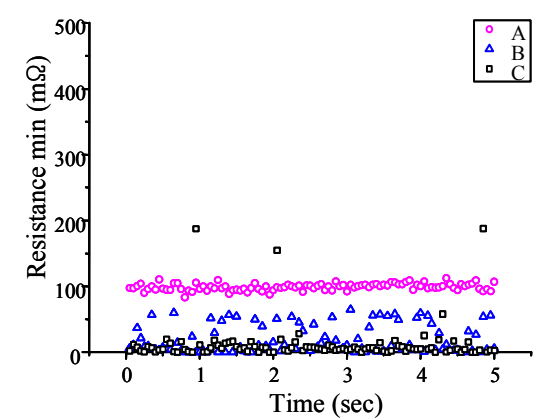

(d) Time series interval : $0.05 \mathrm{~s}$

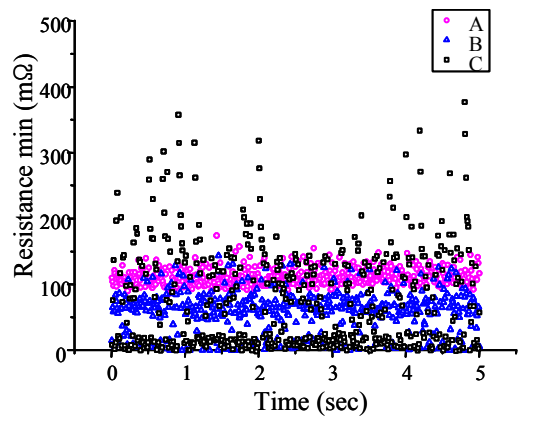

(e) Time series interval : $0.01 \mathrm{~s}$

Fig. 14 Interval statistic results of resistance min

Table 2 Comparison of the correspondence for defect detection

\begin{tabular}{|c|c|c|c|c|c|}
\hline & \multicolumn{5}{|c|}{ Time series interval (s) } \\
\hline & 1 & 0.5 & 0.1 & 0.05 & 0.01 \\
\hline $\mathrm{R}_{\text {avg }}$ & Low & Low & Middle & High & High \\
\hline $\mathrm{R}_{\text {st.dev }}$ & Low & Low & Low & High & Low \\
\hline $\mathrm{R}_{\max }$ & Low & Low & High & High & High \\
\hline $\mathrm{R}_{\min }$ & Low & Low & Low & Low & High \\
\hline
\end{tabular}

\section{후 기}

본 논문은 산업통상자원부 $\mathrm{KEIT}$ 의 연구비 지원에 의 한 연구 결과물임을 밝힙니다. [No : 20003633]

ORCID: Woo-Hyeon Ju: https://orcid.org/0000-0002-3140-8004 ORCID: Hyeong-Chang Ryu: https://orcid.org/0000-0001-5382-6795 ORCID: Kyeong-Seob Lim: https://orcid.org/0000-0001-6733-0643 ORCID: Jong-Jung Lee: https://orcid.org/0000-0003-2414-3906 ORCID: Yong-Hwan Park: https://orcid.org/0000-0002-5280-2764 ORCID: Sang-Myung Cho: https://orcid.org/0000-0001-6258-3625

\section{Reference}

1. T. Quinn, C. Smith, C. McCowan, E. Blachowiak and R. Madigan, Arc sensing for defects in constant-voltage Gas Metal Arc Welding, Weld. J. 79 (1999) 322-328.
2. S. Adolfsson, A. Bahrami, G. Bolmsjo and I. Claesson, On-line quality monitoring in short circuit gas metal arc welding, Weld. J. 78 (1999) 59-73.

3. Y. Chu, S. Hu, W. Hou, P. Wang and S. Marin, Signature analysis for quality monitoring in short-circuit GMAW, Weld. J. 83 (2004) 336-343.

4. D. Farson, C. Conardy, J. Talkington, K. Baker, T. Kerschbaumer and P. Edwards, Arc initiation in Gas Metal Arc Welding, Weld. J. 77 (1998) 315-321.

5. E. Choi, J. Y. Kim, S. H. Shin, S. Y. Kim, A study on the analysis effectiveness of the virtual welding simulator for welding manpower development, J. Weld. Join. 33(3) (2015) 40-46. https://doi.org/10.5781/JWJ.2015.33.3.40

6. W. H. Hong, J. T. Ryu, A study on the welding current and voltage signal processing method for the quality evaluation of robotic GMAW, J. Korea Industr. Inf. Syst. Res.(KSIIS), 19(6) (2014) 321-325. https://doi.org/10.9723/jksiis.2014.19.6.025

7. B. W. Seo, Y. C. Jeong, Y. T. Cho, A study on the Selection of Arc Sensing Signal for Seam Tracking in Pulsed GMAW, J. Weld. Join. 38(2) (2020) 173-179. https://doi.org/10.5781/JWJ.2020.38.2.7

8. J. Y. Park, S. H. Song, Study on the Evaluation of Weld Soundness Based on Arc Stability and Bead Quality using the Statistical Analysis of Arc Power and Arc Dynamic Resistance, J. Weld. Join. 37(6) (2019) 599-604. https://doi.org/10.5781/JWJ.2019.37.6.10 